\title{
Sexual healthcare and contraception provision after sexual assault
}

We would like to share with Journal readers our findings from a local study which highlighted some issues around sexual and reproductive healthcare (SRH) provision after sexual assault which led us to make changes to our local service. People who attend Sexual Assault Referral Centres (SARCs) have a variety of acute and longerterm sexual health and contraceptive needs. In Cardiff, we introduced a local policy in 2017 that aimed to ensure high-quality immediate care within the SARC and onwards referral to the local integrated sexual health clinic. Forensic examinations and immediate care in the SARC are the responsibility of Forensic Medical Examiners (FMEs), employed by a private contractor. The policy followed recommendations from national guidelines,${ }^{1-3}$ through advising on use of post-exposure prophylaxis (PEP) for HIV, hepatitis B vaccination, provision of emergency contraception (EC) and routine referral for sexually transmitted infection (STI) screening. A year later, we conducted an audit to ascertain if the introduction of this protocol had been successful in meeting patients' acute sexual health and contraception needs after sexual assault within the local SARC.

We reviewed SARC and sexual health case notes of all adults attending the SARC between 1 April and 1 July 2018 who met the following criteria:

1. Had a forensic medical examination

2. Acute incident (within the last 7 days).

We reviewed 32 case notes: 29 women, two men and one trans man. 
27/32 patients were referred to the local integrated sexual health service, but only 14/27 (52\%) attended, including 5/7 who started PEP. 2/14 patients (14\%) had a new STI diagnosis (1 chlamydia, 1 herpes simplex virus). EC was discussed with 15/29 women, but only 4/29 were counselled about the copper intrauterine device and none accepted. Provision of oral EC was not in line with Faculty of Sexual \& Reproductive Healthcare (FSRH) guidelines in four cases. $28 / 32$ patients were counselled about hepatitis B vaccination, and eight commenced HIV PEP, but the offer of both appeared to be variable, and risk assessment often subjective.

We were surprised to discover that while most SARC patients are referred to sexual health, many don't attend. This is despite our sexual health clinic being co-located in the same building as the SARC and offering a 'fast-track' appointment for any patient referred from SARC. Furthermore, in the majority (10/13) of cases, the same patients did not engage with follow-up offered by the SARC. Importantly, among those attending, the rate of STIs appears high. Our findings echo experience from other centres; the Haven reported that $45 \%$ of patients did not attend for any follow-up despite all follow-up being offered within the same setting, and in those that did and had an STI test, $12 \%$ were diagnosed with one or more infections. ${ }^{4}$

Although FMEs focus predominantly on identifying forensic evidence for the police, they acknowledged the importance of clients' health needs.
However, immediate care within our SARC appeared variable and not consistently in line with national guidelines. Our study has shown that this may be the only contact the patient has with health services and so needs to be optimised. We feel it is also important to improve follow-up attendance for STI testing as this population appears to have high levels of STIs. We are therefore implementing various changes to attempt to both improve care provided within the SARC and also sexual health clinic attendance. These include first, making baseline STI screening available within the SARC and allowing patients to perform repeat screening at either the SARC or the sexual health clinic; second, producing written patient information about sexual health after sexual assault; and third, offering regular adult peer review and an improved training package for SARC staff around HIV PEP, hepatitis B vaccination and EC.

Sinead Cook $\odot,{ }^{1}$ Laura Cunningham, ${ }^{2}$ Alison Mott ${ }^{3}$

${ }^{1}$ Department of Sexual Health, Cardiff Royal Infirmary, Cardiff, UK

${ }^{2}$ Department of Sexual Health, Cardiff and Vale UHB, Cardiff, UK

${ }^{3}$ Ynys Saff Sexual Assault Referral Centre, Cardiff Royal Infirmary, Cardiff, UK

Correspondence to Dr Sinead Cook, Department of Sexual Health, Cardiff Royal Infirmary, Cardiff CF24 0JT, UK; sineadcook@doctors.org.uk

Funding The authors have not declared a specific grant for this research from any funding agency in the public, commercial or not-for-profit sectors.
Competing interests None declared.

Patient consent for publication Not required.

Provenance and peer review Not commissioned; internally peer reviewed.

(C) Author(s) (or their employer(s)) 2020. No commercial re-use. See rights and permissions. Published by BMJ.

A Check for updates

Published Online First 5 November 2019

BMJ Sex Reprod Health 2020;46:82-83.

doi:10.1136/bmjsrh-2019-200356

ORCID ID

Sinead Cook http://orcid.org/0000-00029415-6174

\section{REFERENCES}

1 Clinical Effectiveness Group, British Association for Sexual Health and HIV. UK national guidelines on the management of adult and adolescent complainants of sexual assault 2011. BASHH Guidance 2011.

2 Cresswell F, Waters L, Briggs E, et al. UK guideline for the use of HIV post-exposure prophylaxis following sexual exposure, 2015. Int J STD AIDS 2016;27:713-38.

3 Faculty of Sexual \& Reproductive Healthcare (FSRH). CEU clinical guidance: emergency contraception, 2017. Available: https://www.fsrh. org/documents/ceu-clinical-guidanceemergency-contraception-march-2017/ [Accessed 7 Jan 2019].

4 Kerr E, Cottee C, Chowdhury R, et al. The Haven: a pilot referral centre in London for cases of serious sexual assault. BJOG 2003;110:267-71. 